\author{
تلفيق مدلهاى تصميم گيرى جندمعياره مكانى در ارزيابى سناريوهاى تخصيص آب

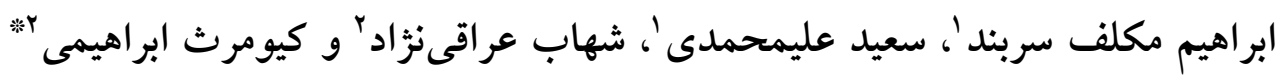

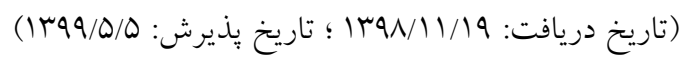

جكيده

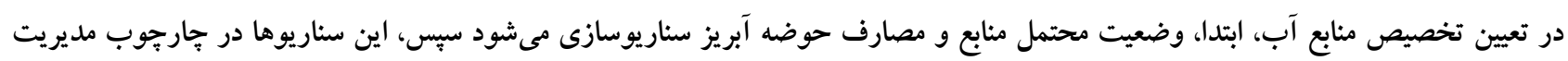

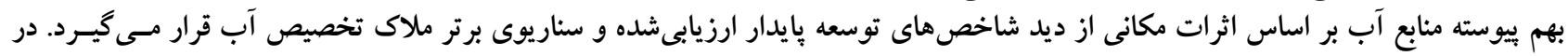

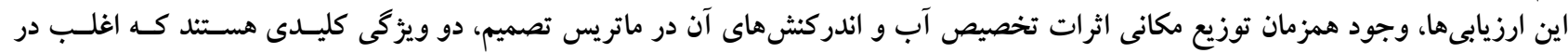

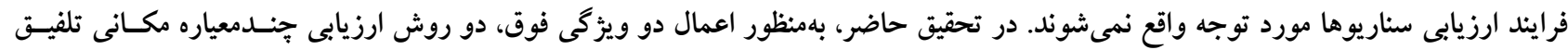

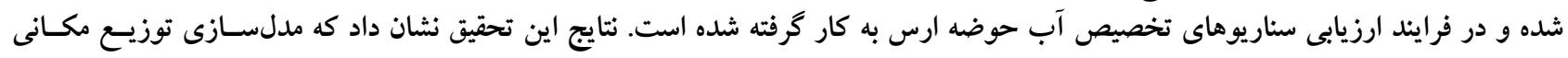

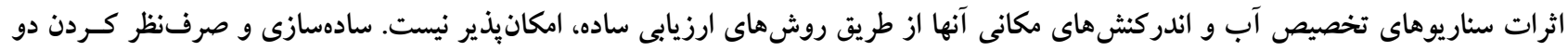

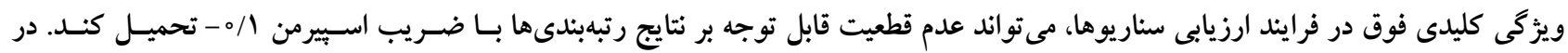

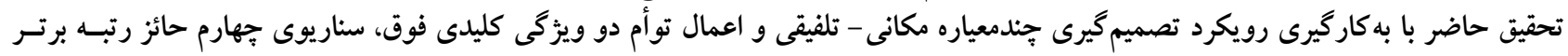

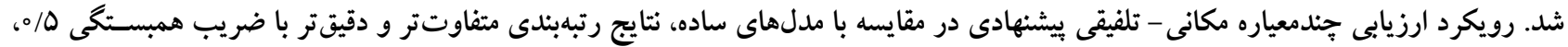


و رتبهبندىها را دجار تغيير قابل توجه كند (YT).

در فرايند ارزيابى اثرات سناريوهاى تخصسيص آب، توزيـع مكانى و اندركنشهاى مكانى از نقش بارزترى برخوردار بوده و

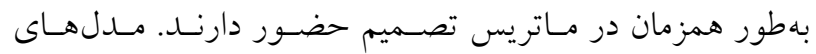
ارزيابى جندمعياره هر كدام بهتنهايى قابليت مدلسازى تـوأم دو

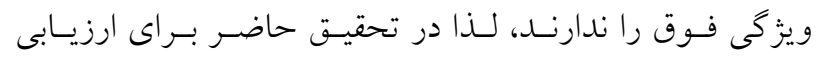

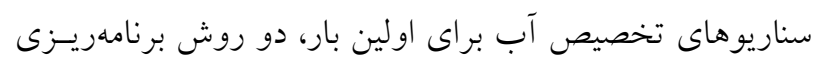
سازشى و تحليل شبكهاى تلفيق شده و با شاخص هاى تـوزيعى

به كار برده شده است. اهداف اين تحقيق عبارت است از: - تعريف شاخص هاى ارزيـابى مكـانى، ايجـاد سـاختار شـبكه

$$
\text { كلاسترهاى ماتريس تصميم تخصيص آب }
$$

- تعيـين وزن اهميـت المـانهـاى تصـميم و اولويست نهـايى سناريوهاى تخصيص آب با احتساب اندركنشهاى موجود

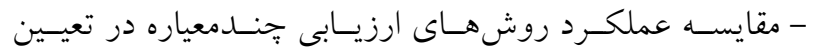
اولويتهاى نهايى سناريوها

\section{مواد و روشها}

مبانى روش هاى تصميم گيرى جندمعياره تحليل شبكهاى: يكى از روشهاى بركاربرد در تصميم گيرىهاى جندمعياره، فرايند تحليل شـبكهاى اسـت كـه تعمسيميافتـه روش تحليل سلسله مراتبى با ساختار شبكهاى است. در فراينــ تحليـل سلسله مراتبى، وابستكى ها بهصورت خطى و از بالا به بايين است

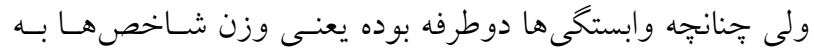
سناريوها و وزن سناريوها به شاخص ها وابسـتخى داشـته باثــند، مسئله تصميم گيرى از حالت سلسلهمراتبى خارج مىشود. در ايسن حالت، يك شبكه و سيسـتم غيرخطى تشـكيل شــده كـه در آن، قوانين و روابط روش تحليل سلسله مراتبى معتبر نخواهد بود. بـهـ همين دليل، ساعتى (T) نظريه خـود درخصـوص روش تحليـل سلسلهمراتبى را كسترش داد و ساختار شبكهاى را بيشـنهاد كـرد. در اين ساختار اندركنش ها، وابستكى ها، جــه درونسى (درون يـى كلاستر) و جهه بيرونى (بين شاخصها و معيارها و سناريوها)، بين

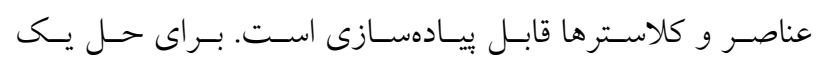

در تعيين تخصيص منابع آب، ابتـدا وضـعيت محتمـل منـابع و مصارف در مقياس حوضه آبريز سناريوسازى مسىشـود. سـبس سناريوها در جارجوب مديريت بهم بيوسـته منـابع آب از ديـــ شاخصهاى توسعه يايدار (N) ارزيابى مىشود و سناريوى برتـر ملاكى تخصيص منابع آب قرار مى گيرد. مدلهاى تصسميم گيسرى جندمعياره در زمينههاى مختلف كـاربرد وسـيعى داشسته (سا) و در مديريت و برنامهريزى منابع آب نيز كاربردهاى متنوع از اين مدلها وجود دارد (9). مطالعات انجام شده نشان داده است كـهـ استفاده از توزيع مكانى مقــادير بـهـهــاى مقــدار متوسـط آن در حوضه موجب افزايش دقت تخمسينهـا مسىشـود (سو V). در زمينـهُ مـــيريت و برنامـهريـزى منــابع آب، روش برنامسهريـزى سازشىى در ارزيـابىهــا بـا شـاخصىهـاى مكـانى، كاربردهـاى وسيعترى داشته است (1) در جدول (1)، ارزيابىهاى جندمعياره به كار برده شده به لحساظ نوع شاخص و روش ارزيابى جندمعياره دستهبندى شــده اسـت. در اين ارزيابى ها، بيشتر سادهازى شده و از توزيـع مكـانى مقــادير و اندركنش هاى مابين المانهاى مـاتريس تصـميم صـرف نظـر شــه است. در اين تحقيقات، از شـاخصهــاى تـودهاى و مــدل ارزيـابى

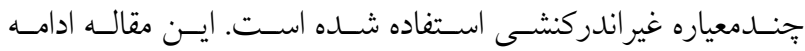
يزوهشى از مؤلفين است (Y (1) كه نتايج آن نشان داد كه در ارزيـابى سناريوهاى تخصيص آب، نوع شاخص به لحاظ تـودهاى بـودن يـا توزيعى بودن و يا بهعبارت بهتر توزيع مكـانى مقـادير، تـأثير قابـل ملاحظهاى در فرايند ارزيابى سناريوها و نتايج رتبـهبنـدى آن دارد و روش برنامهريزى سازشى، عملكرد بهتـرى در مــل كـردن توزيـع مكانى مقادير دارند. وليكن روش برنامهريزى سازشى فاقـد قابليـت مدلسازى اندركنش هاى مابين المانهاى تصميم اسـت. در مسـائل

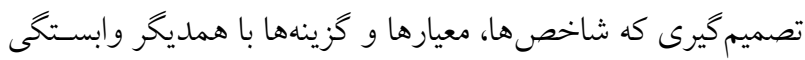

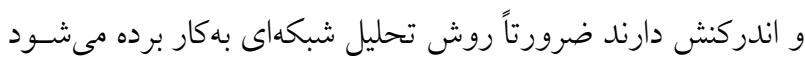

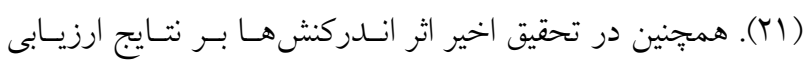

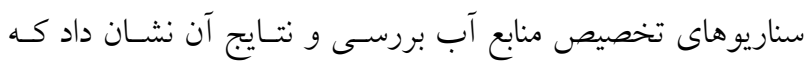
سادهسازى و صرفنظر كردن از اندركنشها مىتواند نتايج ارزيـابى 
جدول ا. كاربردهاى مدلهاى تصميم گيرى جندمعياره در زمينه مديريت و برنامهريزى منابع آب

\begin{tabular}{|c|c|c|c|c|c|c|c|}
\hline \multicolumn{3}{|c|}{ نوع شاخص } & \multicolumn{3}{|c|}{ نوع روش ارزيابى جندمعياره } & \multirow{2}{*}{ محققين } & \multirow[t]{2}{*}{ زمينه كاربرد } \\
\hline توزيعى & تودهاى & 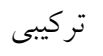 & اندركنشى & 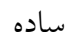 & 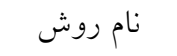 & & \\
\hline 口 & $\nabla$ & 口 & 口 & $\nabla$ & $\mathrm{CP}, \mathrm{SA}$ & ضرغامى و همكاران (YN) & تأمين آب شهرى \\
\hline$\square$ & 甲 & $\square$ & 口 & $\square$ & $\mathrm{CP}$ & ابريشمجى و همكاران (1) & \\
\hline 口 & $\square$ & $\square$ & $\square$ & च & AVF & يانگ و همكاران (YV) & رتبهبندى سناريو هاى مديريت منابع \\
\hline 口 & $\nabla$ & 口 & 口 & च & OPSIS & كيم و همكاران (11) & \\
\hline$\nabla$ & $\square$ & 口 & 口 & $\nabla$ & $\mathrm{CP}$ & يرادونويج و سيمونويج (1) & ارزيابى اثرات سناريوهاى مديريت \\
\hline$\square$ & $\nabla$ & $\square$ & 口 & $\nabla$ & AHP & ثردويج و مديوريس (Tr) & \\
\hline 口 & $\nabla$ & 口 & $\square$ & $\nabla$ & VIKOR & إبريكوويج (IV) & برنامهريزى بايدار \\
\hline$\square$ & 甲 & $\square$ & 口 & $\square$ & $\mathrm{CP}$ & كَنخ و والدراو (9) & \\
\hline$\square$ & $\square$ & $\square$ & $\square$ & $\square$ & AHP & متتظر و زادباقر (14) & تصميم گيرى در مسائل اقتصادى- \\
\hline 口 & $\nabla$ & $\square$ & 口 & $\square$ & TOPSIS & افشار و همكاران (r) & رتبهبندى حالشهاى منابع آب \\
\hline 口 & $\square$ & $\square$ & 口 & $\square$ & AHP & ملكمحمدى و همكاران (TI) & \\
\hline 口 & 曰 & 口 & 口 & $\nabla$ & $\mathrm{CP}$ & هاجكويتز و هيقنز (10) & ارزيابى استراتزى هاى مديريت منابع \\
\hline$\square$ & $\square$ & $\square$ & $\square$ & च & ANP,VIKOR & رضوى طوسى و سامانى (YY) & \\
\hline$\square$ & $\nabla$ & $\square$ & $\square$ & $\square$ & AHP & متتظر و اشنايدر (10) & الكُوى كشت و سيستم آبيارى \\
\hline$\nabla$ & $\square$ & $\square$ & $\square$ & $\square$ & AHP,TOPSIS & رامهر و عراقىنزاد (19) & ارزيابى آسيبذيذيرى در برابر \\
\hline 曰 & $\square$ & $\square$ & $\square$ & $\square$ & AHP & راهدارى و همكاران (Yo) & قابليت اراضى كشاورزى ديم \\
\hline 甲 & $\square$ & $\square$ & $\square$ & 甲 & ANP ,AHP & سربند و همكاران (YT) & تخصيص منابع آب \\
\hline$\square$ & $\square$ & $\square$ & $\square$ & $\square$ & $\mathrm{CP}$ & مكلف سربند و همكاران (1) & \\
\hline
\end{tabular}

به نظير ضرب شده و ماتريس وزنى را تشـكيل مسىهــــ مـاتريس

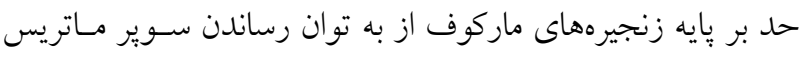

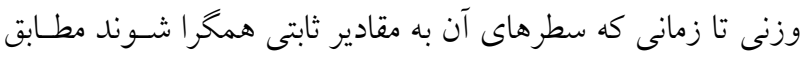

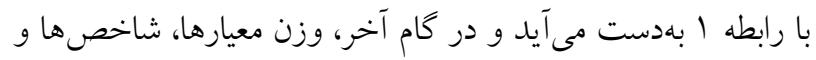

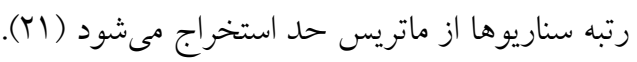

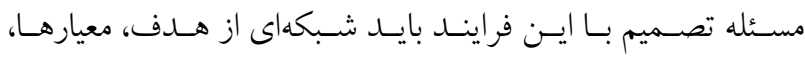

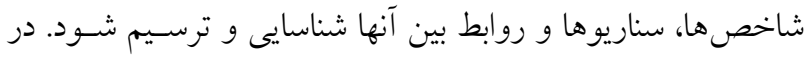

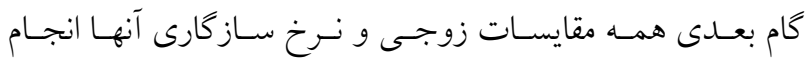

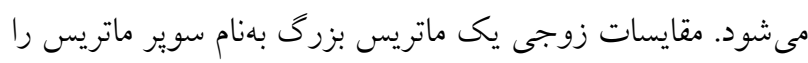
تشكيل مىدهند. اين سوير ماتريس در ماتريس وزن خروههـا نظيـر 
شناسايى شدند (^). فراينـــ ارزيـابى سـناريوها بـا تلفيـق دو مــل

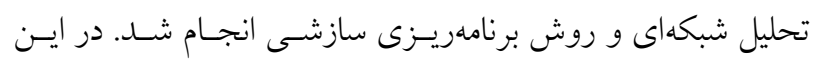

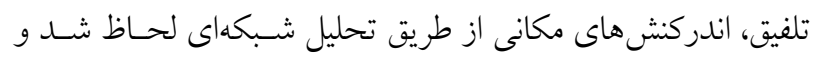

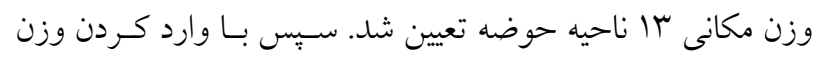

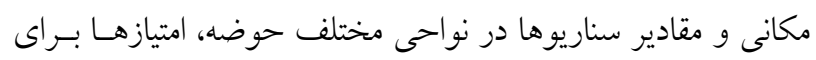
هر سناريو از ديد بانزده شاخص، تجميع و امتياز نهايى هـر سـناريو

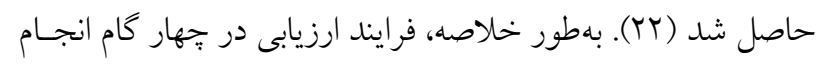

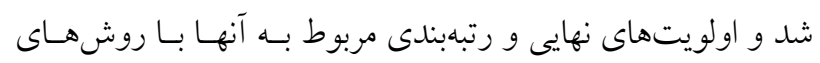
مختلف تعيين و از طريق ضريب همبستخى اسبيرمن مقايسه شـدند.

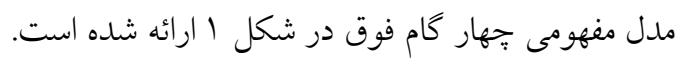

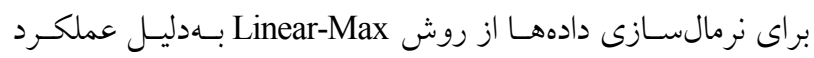

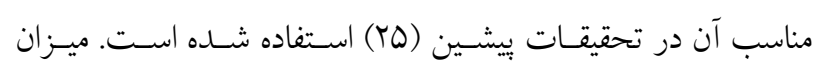

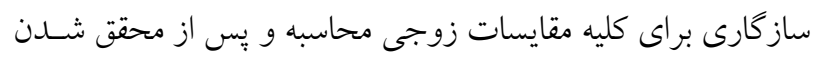

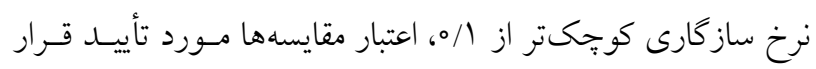

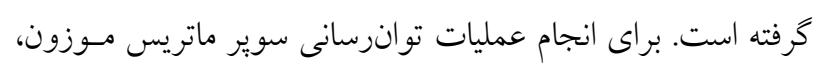

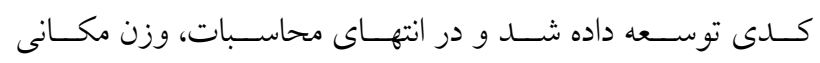

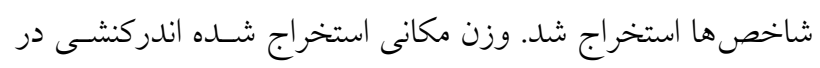

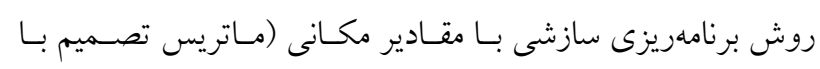

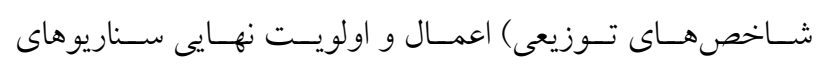

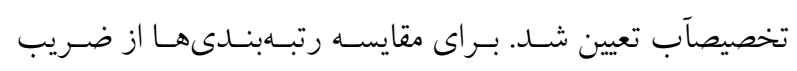

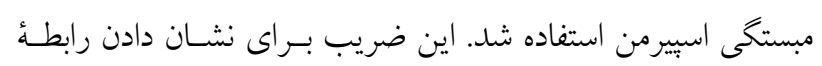

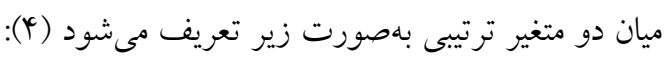
$r_{s}=1-\frac{6 \sum_{\mathrm{i}=1}^{\mathrm{n}} \mathrm{D}^{2}}{\mathrm{n}\left(\mathrm{n}^{2}-1\right)}$

كه در آن، D تفـاوت بـين رتبـههــاى اعضـاى متنـاظر دو روش تصميم گيرى جند شاخصه و n تعداد سناريوهاست.

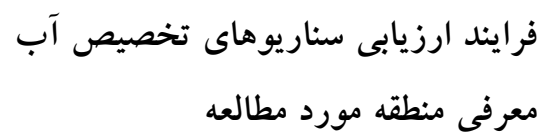

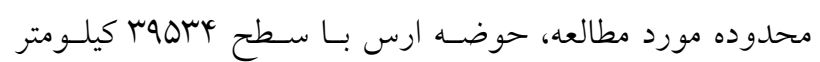

Limit Matrix $=\lim _{\mathrm{K} \rightarrow \infty}(\mathrm{W})^{\mathrm{K}}$

كه در آن، Limit Matrix سوير ماتريس حد، W سوير مـاتريس وزندار و K توان سوير ماتريس وزندار است.

روش برنامهريزى سازشسى CP: روش برنامـهريـزى سازشى

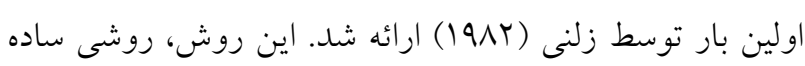

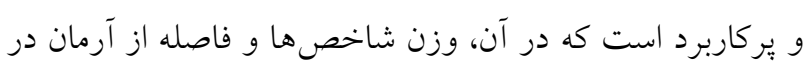

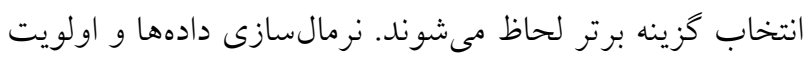
نهايى از روابط زير محاسبه مىشوند (YN): $\overline{a_{i j}}=\frac{a_{i j}-m_{j}}{M_{j}-m_{j}}$

$\overline{a_{i j K}}=\frac{a_{i j K}-m_{j}}{M_{j}-m_{j}}$

$\mathrm{F}_{i}=\left(\sum_{\mathrm{j}=1}^{\mathrm{n}} \mathrm{a}_{\mathrm{ij}}-\mathrm{p} * \mathrm{w}_{\mathrm{j}}^{\mathrm{p}}\right)^{1 / \mathrm{p}}$

در روابط بـالا، a a a a a a

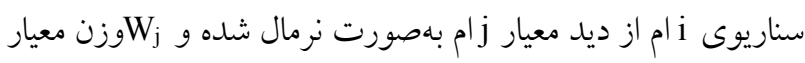
ز ام است. P بارامترى كه حساسيت تصميم كير بـهـ فاصـله از نقطـه نامطلوب را برحسب شاخص هاى مختلـف بيـان مسى كنــ؛ كـه در

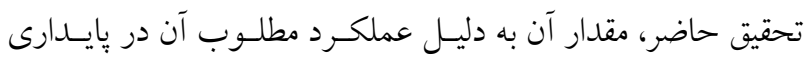

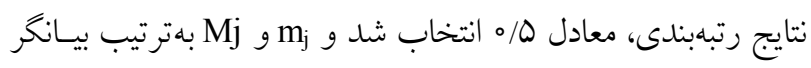
كمترين و بيشترين مقادير گزينهها يا سناريوها هستند.

رويكرد ارزيابى جندمعياره مكانى - تلفيقى تحقيق حاضر

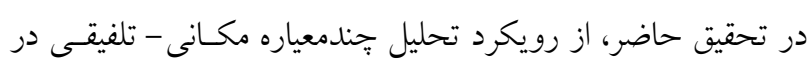

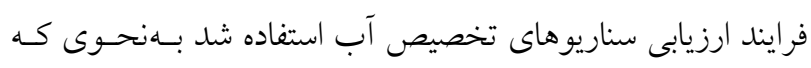

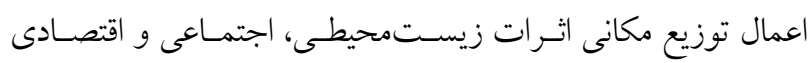

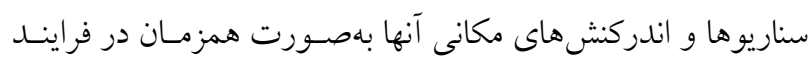

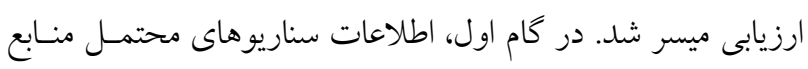

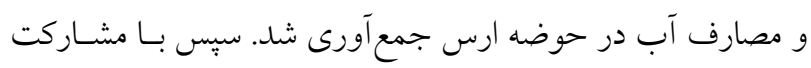

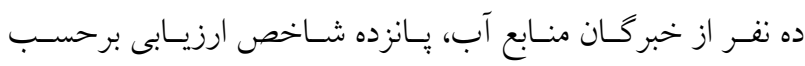

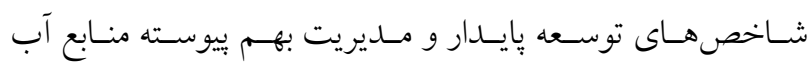




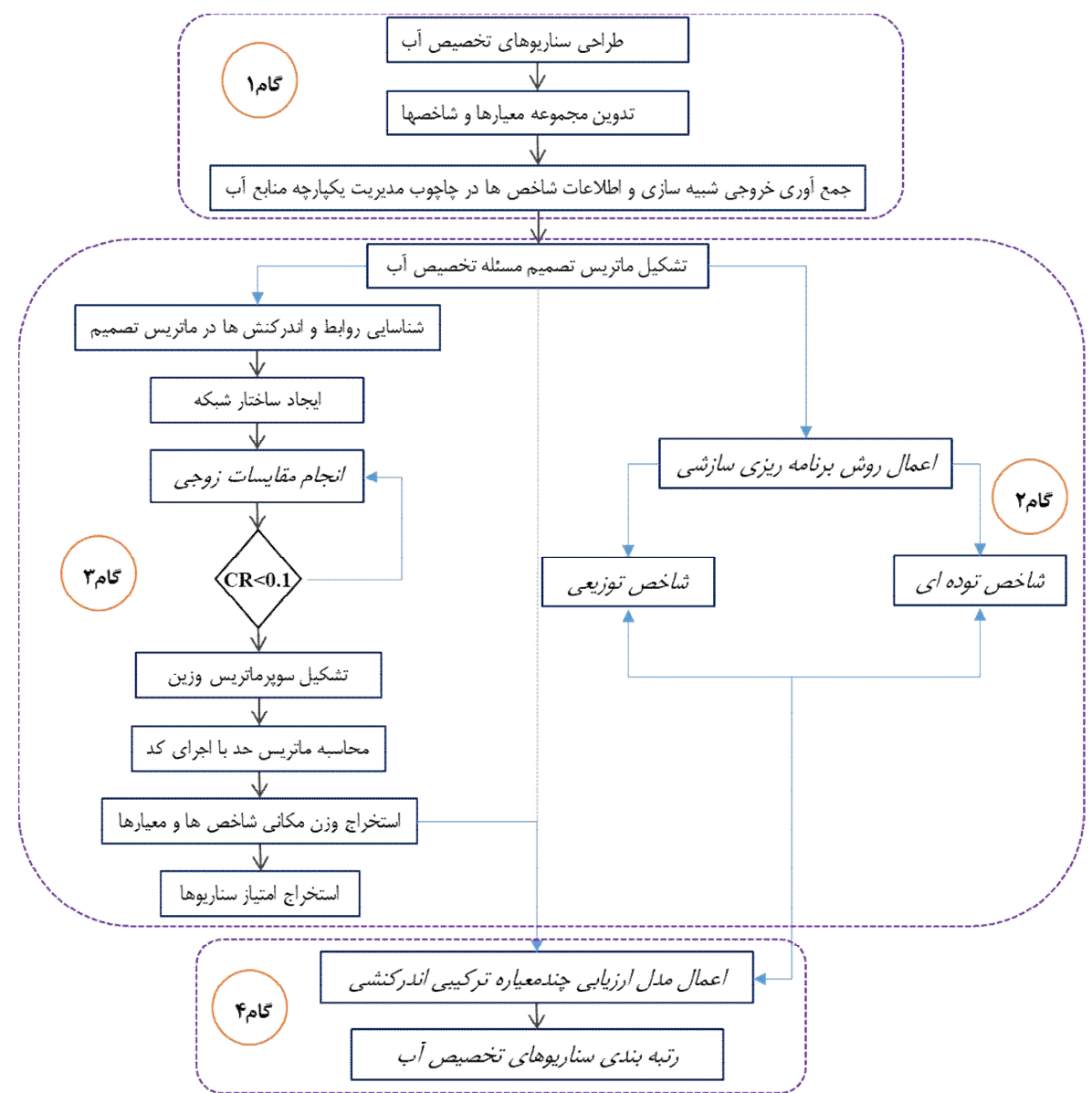

شكل 1. مدل مفهومى تلفيق دو روش ارزيابى جندمعياره مكانى و اندر كنشى

معيارها و شاخص هاى ارزيابى

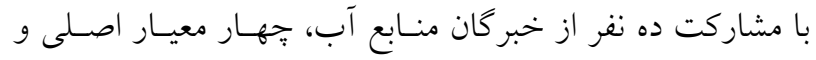

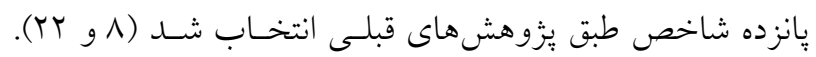
اطلاعات سناريوهاى تخصيص منابع آب حوضه ارس به همدراه

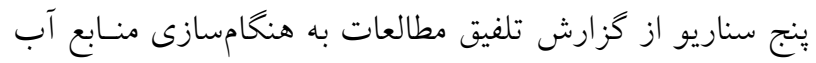

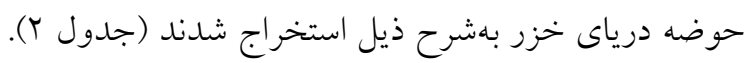
آب در دسـترس (WR): ايسن معيـار بيـانكر بيكربنـــى منــابع و

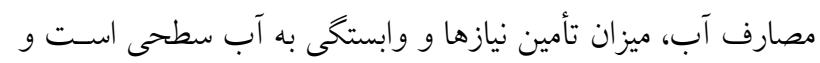
شامل سه شاخص مكـانى: آب خروجسى از كشـور (WR

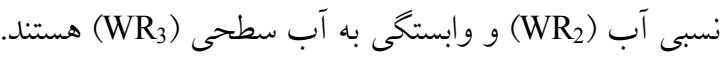

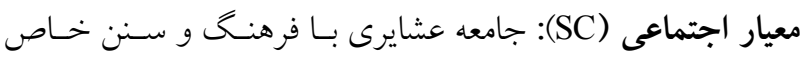

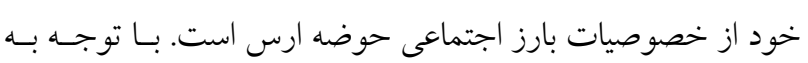

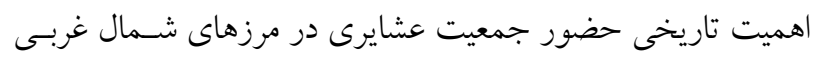

مربع است كه در شمال غربى ايران واقـع شـده و بخشسى از

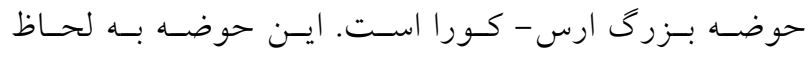
تقسيمات كشورى، بخشهايى از سـه اسـتان شـامل اردبيـل،

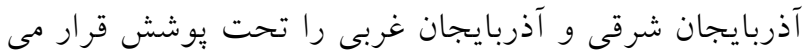
دهد (شكل r). در اين حوضه، سرمايه كذارى قابل ملاحظـهـ

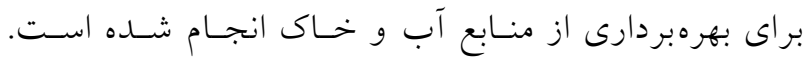

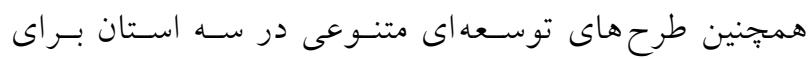

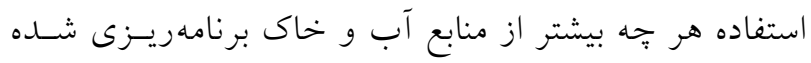

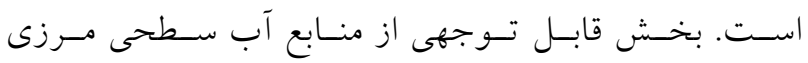

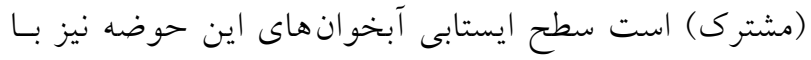

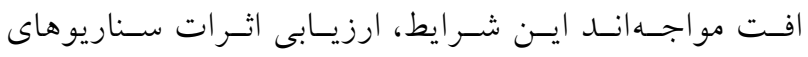

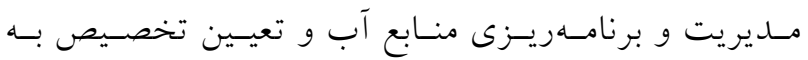
كاربرهاى مختلف را حائز اهميت كرده است. 


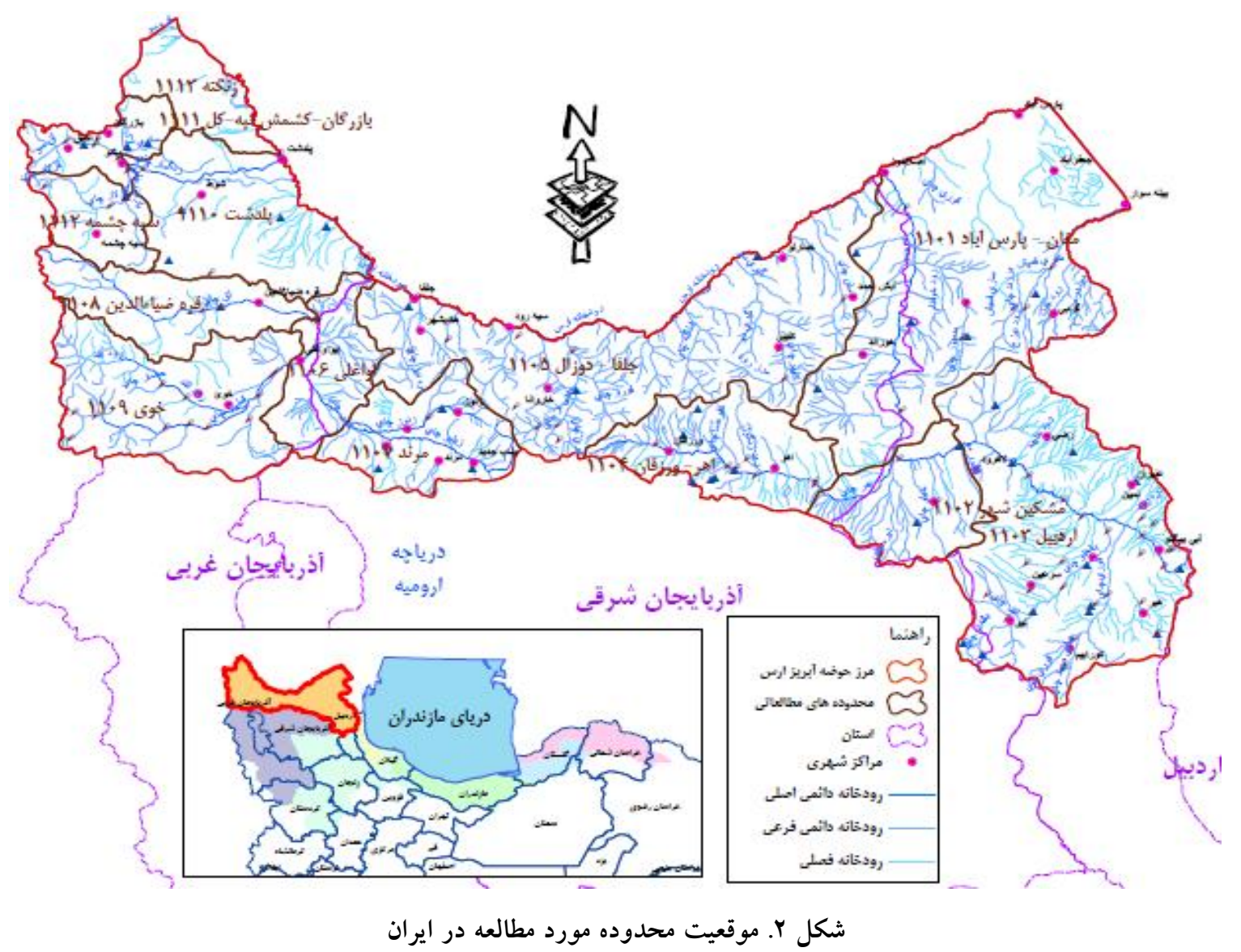

جدول r. مشخصات مجموعه معيارها و شاخص هاى مكانى

\begin{tabular}{|c|c|c|c|c|c|}
\hline مرجع شاخص & واحد شاخص & محدوده تعريف & نام اختصارى & شاخص & معيار مع \\
\hline IME & Cardinal & rا ناحيه & $\mathrm{EV}_{1}$ & كيفيت آب & 3 \\
\hline IME & Cardinal & با باحيه & $\mathrm{EV}_{2}$ & محدوديت توسعه & \\
\hline UNEP, UN & Cardinal & با باحيه & $\mathrm{EV}_{3}$ & اكوسيستم وابسته به آب & $y$ \\
\hline IME & متر مكعب & با ناحيه & $\mathrm{EV}_{4}$ & نيازهاى غيرمصرفى & 凷 \\
\hline IME & نفر & سه استان & $\mathrm{SC}_{1}$ & مشاركت عشاير & \multirow{4}{*}{$\begin{array}{l}\bar{y} \\
3 \\
y \\
0 \\
0\end{array}$} \\
\hline (5) Falken Mark & متر مكعب بر نفر & با ناحيه & $\mathrm{SC}_{2}$ & سرانه آب & \\
\hline IME & ل درصد & با باحيه & $\mathrm{SC}_{3}$ & اشتغال & \\
\hline IME & نفر & سه استان & $\mathrm{SC}_{4}$ & جمعيت & \\
\hline IME & 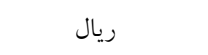 & كا باحيه & $\mathrm{EC}_{1}$ & سرمايه كذارى انجامشده & \multirow{4}{*}{ 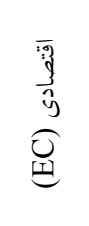 } \\
\hline FAO & ريال بر متر مكعب & سه استان & $\mathrm{EC}_{2}$ & كارايى مصرف آب & \\
\hline FAO & كيلو گرم در هكتار & سه استان & $\mathrm{EC}_{3}$ & كارايى توليد محصول & \\
\hline IME & هكتار & كا باحيه & $\mathrm{EC}_{4}$ & اراضى حاصلخيز & \\
\hline IME & متر مكعب & حوضه & $\mathrm{WR}_{1}$ & آب خروجى از حوضه & \multirow{3}{*}{ 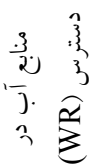 } \\
\hline UNH & درصد & rا ناحيه & $\mathrm{WR}_{2}$ & تنش نسبى آب & \\
\hline IME & ل درصد & rا ناحيه & $\mathrm{WR}_{3}$ & وابستخى به آب سطحى & \\
\hline
\end{tabular}


ناشى از تغييـرات اقليمسى و سـاز كارى بـا آن، سـناريوى يــنجم

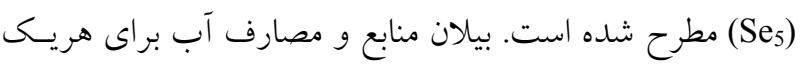

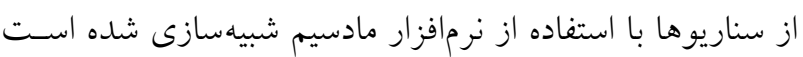

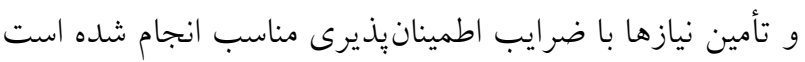
از نتايج اين شبيهسازىها در تحقيق حاضر استفاده شد.

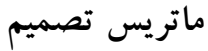

شاخصها به دو صورت تودهاى و تـوزيعى مشـتمل بـر جهـار

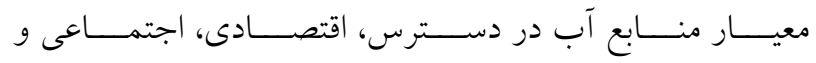
زيستـمحيطى هسـتند. اطلاعـات سـناريو ها، مـاتريس مسـئله تخصيص آب را تشـكيل دادهانــ. ابعـاد ايسن مـاتريس تصـميم

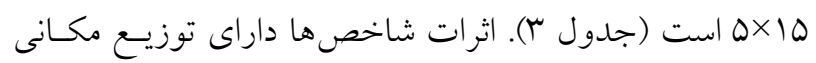

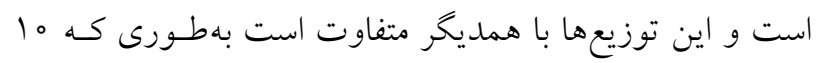

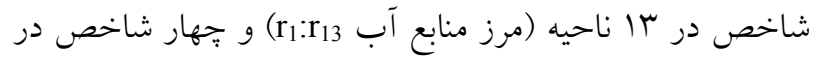

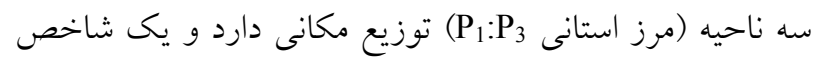

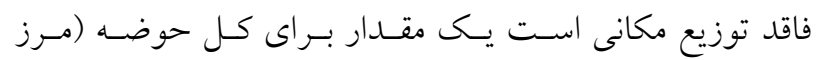

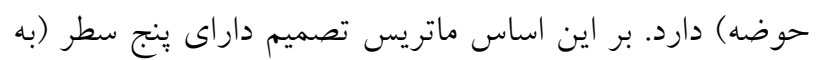

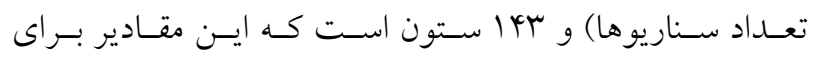
شاخصهاى توزيعى مورد استفاده قرار كرفتهاند.

\section{نتايج}

\section{ساختار شبكه كلاسترها و سوير ماتريس آن}

ساختار شبكه به كار رفته در مقاله حاضر با توسعه و تكميـل نتسايج

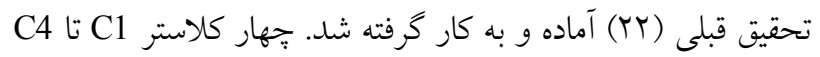

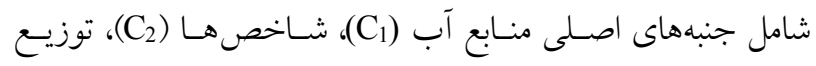

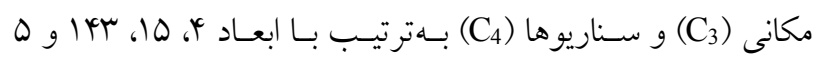

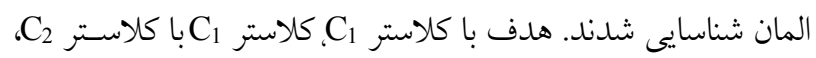

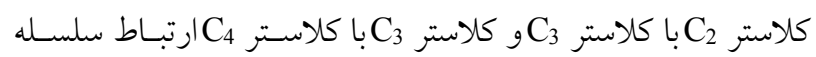

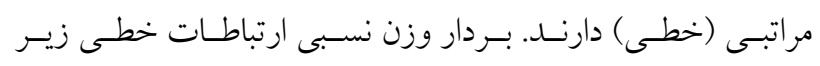

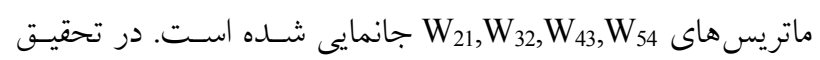
حاضر، سه نوع اندركنش لحاظ شده است كه عبارتاند از:
كشور، معيار اجتماعى در حوضه ارس شامل جهار شاخص مكـانى:

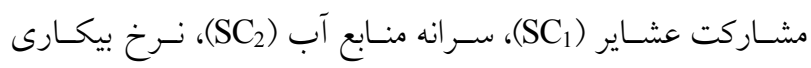
و جمعيت (SCl $)$

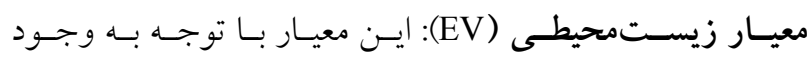

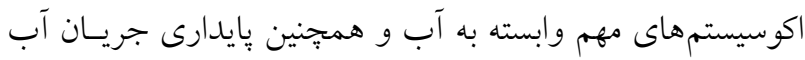

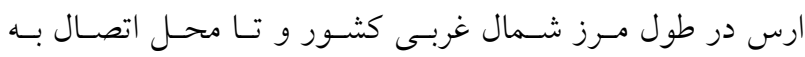

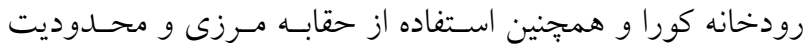
هاى توسعهاى در نظر كرفته شــه اسـت. معيـار زيستـمحيطى

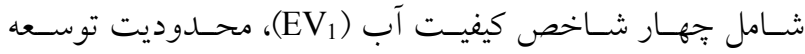
(EV2)، اكوسيستمهاى وابسته به آب (EV) محيطى (EV) براى بايدارسازى جريان است.

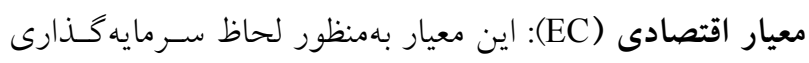

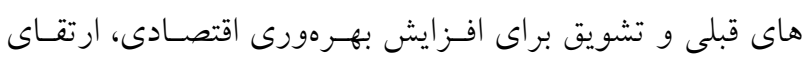

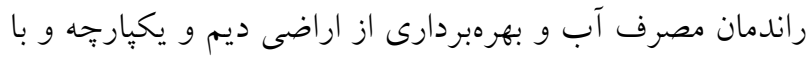

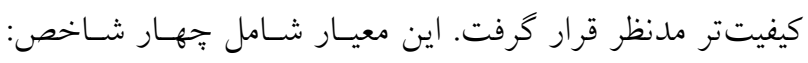

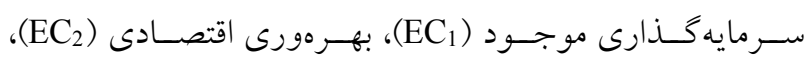

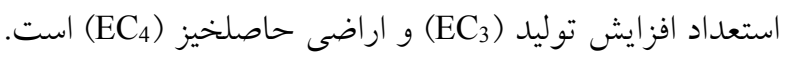

\section{سناريوهاى تخصيص منابع آب}

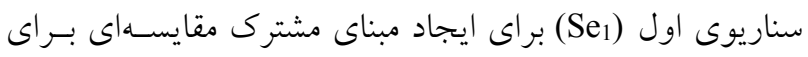

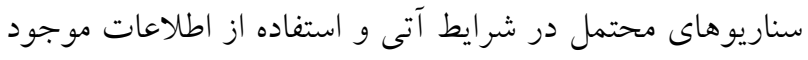

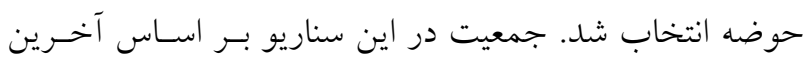

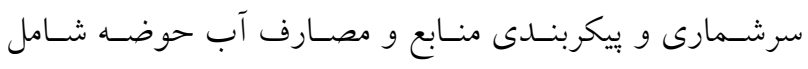

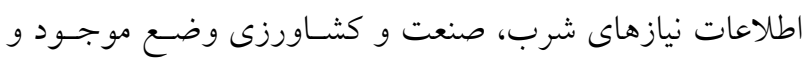

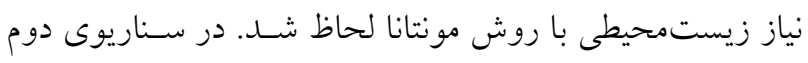

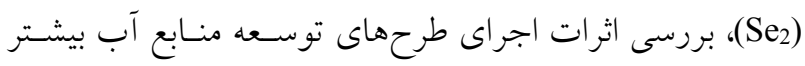

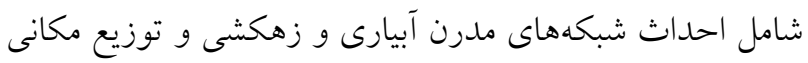

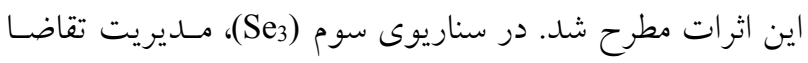

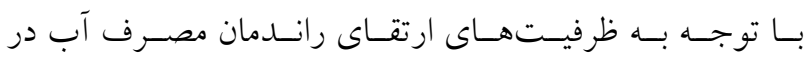
كشاورزى با آبيارى تحت فشار، مطرح شد. تعادل بخشى منسابع

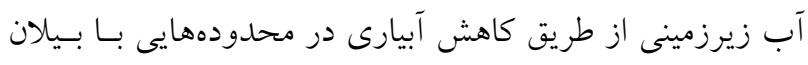

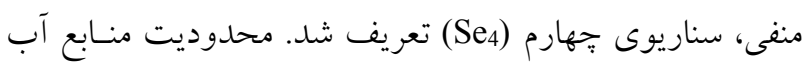


جدول r. ماتريس تصميم با شاخص هاى تودهاى

\begin{tabular}{|c|c|c|c|c|c|c|c|c|}
\hline $\mathrm{EV}_{4}$ & $\mathrm{EV}_{3}$ & $\mathrm{EV}_{2}$ & $\mathrm{EV}_{1}$ & $\mathrm{EC}_{4}$ & $\mathrm{EC}_{3}$ & $\mathrm{EC}_{2}$ & $\mathrm{EC}_{1}$ & \\
\hline $0 / 094$ & 0.094 & 0.094 & $0 / 04 Y$ & $0 / 09 Y$ & $0 / 09 Y$ & $0 / 09 Y$ & 0.094 & سناريوها \\
\hline $\mathrm{B}_{8} \times 10^{6}$ & $\mathrm{~B}_{7}$ & $\mathrm{~B}_{6}$ & $\mathrm{~B}_{5}$ & $\mathrm{~B}_{4} \times 10^{3}$ & $\mathrm{~B}_{3}$ & $\mathrm{~B}_{2}$ & $\mathrm{~B}_{1} \times 10^{13}$ & \\
\hline $10 Y 9$ & $r / T$ & $0 / 1 \Gamma$ & $v / r q$ & rNr & - ( & 1KG。 & V & وضع موجود \\
\hline TGAV & $T / T$ & Q/N & $v / r q$ & 010 & ०/Ar & $1 Y \varphi_{0}$ & $\wedge$ & اجراى طرحهاى توسعه \\
\hline TVYG & $r / T$ & $0 / 1 T$ & $V / r q$ & 010 & $\circ / \Lambda \mu$ & 1140 & $\wedge$ & مديريت تقاضا \\
\hline TVYG & $r / T$ & D/R & $v / r q$ & 010 & $\circ / \wedge Y^{\prime}$ & $1 Y 40$ & $\wedge$ & تعادل بخشى آب زيرزمينى \\
\hline rova & $r / T$ & $r / 91$ & $4 / 19$ & 010 & $0 / 9 r$ & $1 \mu_{0}$ & $\wedge$ & خشكسالى و تغيير اقليم \\
\hline $\mathrm{WR}_{3}$ & $\mathrm{WR}_{2}$ & $\mathrm{WR}_{1}$ & & $\mathrm{SC}_{4}$ & $\mathrm{SC}_{3}$ & $\mathrm{SC}_{2}$ & $\mathrm{SC}_{1}$ & \\
\hline$\circ / \circ \wedge \mu$ & $\circ / 0 \wedge r$ &.$/ 0 \wedge \mu$ & & $0 / 04 Y$ & $0 / 094$ & $0 / 094$ & $0 / 094$ & سناريوها \\
\hline $\mathrm{B}_{15}$ & $\mathrm{~B}_{14}$ & $\mathrm{~B}_{13} \times 10^{9}$ & & $\mathrm{~B}_{12} \times 10^{5}$ & $\mathrm{~B}_{11}$ & $\mathrm{~B}_{10}$ & $\mathrm{~B}_{8} \times 10^{3}$ & \\
\hline$\circ / V Y$ & $1 / 00$ & $r$ & & 9 & $9 / 10$ & 1491 & 10 & وضع موجود \\
\hline o/AF & $1 / 10$ & r & & $\wedge$ & G/AV & 1100 & rI & اجراى طرحهاى توسعه \\
\hline$\circ / \wedge \circ$ & $1 / 44$ & $r$ & & $\wedge$ & G/AV & 1100 & rI & مديريت تقاضا \\
\hline$\circ / \Lambda 1$ & $1 / 4 V$ & r & & $\wedge$ & G/AV & $\operatorname{losr}$ & rI & تعادل بخشى آب زيرزمينى \\
\hline$\circ / V \wedge$ & $1 / 19$ & 1 & & $\wedge$ & $\Lambda / \mu K$ & V*4 & IV & خشكسالى و تغيير اقليم \\
\hline
\end{tabular}

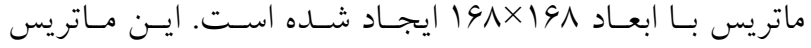
دربر گيرنده كليه ارتباطات ممكن در بين المانهاى تصميم شامل روابط بيرونى، داخلى و بازخوردهـا اسـت. در تحقيـق حاضـر، هشـت زيــر مـاتريس: هـ داراى ارزش عددى و I ماتريس واحد است. اين زير ماتريسها در موقعيتهاى مختلف سوير ماتريس قرار داشته و شـش زيــر ماتريس، دوبهدو در يك ستون جاى گرفتهاند (شكل \&).

وزن اهميت المانهاى تصميم وزن اهميت المانهاى تصميم با اعمـال انسـركنش هــا از طريـق سوير ماتريس حد در طى انجـام تحليـل شـبكهاى (19) تعيسين

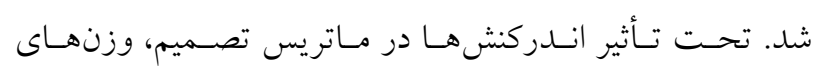
متفاوتى نسبت به وزنهـاى مشـابه مفـروض، از مـاتريس حـــ حاصل مسىشـود. وزن هشـت شـاخص، كـاهش و وزن هفتـ شـاخص، افـزايش يافتـه اسـت. ضـريب همبسـتخى وزنهـاى مفروض با وزنهـاى اندركنشى بـه مقـدار سم/ه بيـانخر تـأثير
- در كلاستر C1 قابليت دسترسى منابع آب در سطح كلان مستقل از هم نبـوده و بههم وابستهاند، بردار وزن اين وابستكى ها با مقايسـات زوجسى بهدست آملده و در زير ماتريس W22 اعمال شده است.

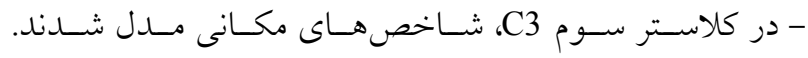
المانهاى اين كلاستر توزيع مكانى اثرات اجتماعى، اقتصـادى و زيست محيطى سناريوهاى تخصيص منابع آب را در خود جـاى دادهاند اين المـانهـا مسـتقل از هــم نبـوده و تعـداد هو مـورد وابستكى بين آنها شناسايى شده است بـردار وزن متنـاظر آن در زير ماتريس W44 لحاظ شده است.

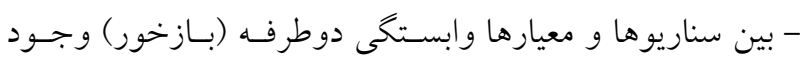
دارد ايسن وابسـتخى (وابسـتخى دو كلاسـتر C4 و C2) بـا زيـر ماتريس W25 اعمال شده است همجنين اين نوع وابستخى بسين كلاسترهاى C4 و C3 وجود دارد كه زير مـاتريس W45 متعلـق به آن است (شكل با). سوير مـاتريس ارزيـابى سـناريوهاى تخصـيص آب از هr زيـر 


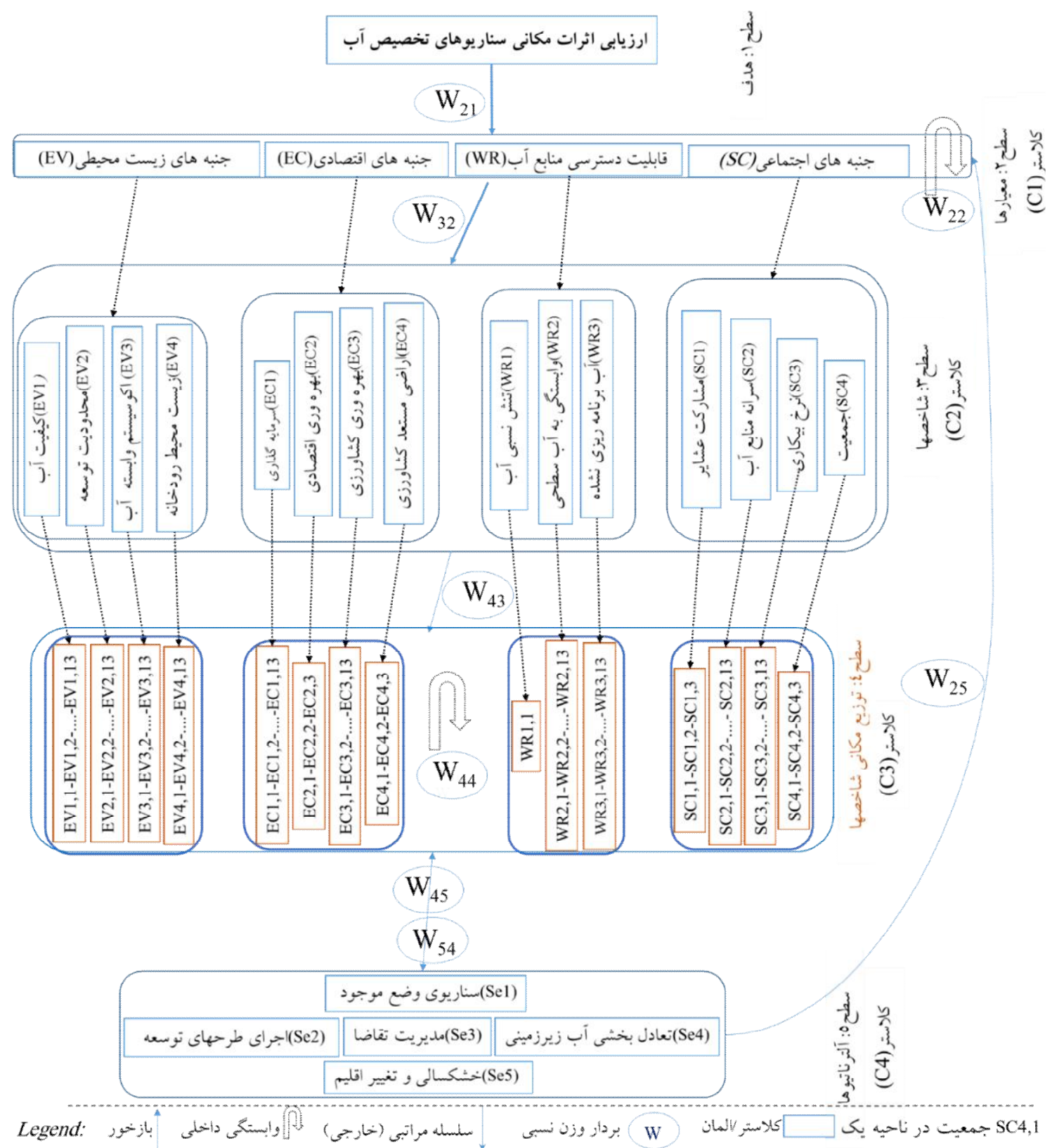

شكل r. نمادين ساختار شبكه ماتريس ارزيابى سناريوهاى تخصيص منابع آب

$\left(\begin{array}{lllll}W_{11} & W_{12}^{\prime} & W_{13}^{\prime} & W_{14} & W_{15}^{\prime} \\ W_{21} & W_{22} & W_{23}^{\prime} & W_{24}^{\prime} & W_{25} \\ W_{31}^{\prime} & W_{32} & W_{33}^{\prime} & W_{34}^{\prime} & W_{35}^{\prime} \\ W_{41}^{\prime} & W_{42}^{\prime} & W_{43} & W_{44} & W_{45} \\ W_{51} & W_{52} & W_{53} & W_{54} & W_{55}\end{array}\right) \rightarrow\left(\begin{array}{ccccc}0 & 0 & 0 & 0 & 0 \\ W_{21} & W_{22} & 0 & 0 & W_{25} \\ 0 & W_{32} & 0 & 0 & 0 \\ 0 & 0 & W_{43} & W_{44} & W_{45} \\ 0 & 0 & 0 & W_{54} & I\end{array}\right)$

شكل f. سوير ماتريس ارزيابى سناريوهاى تخصيص منابع آب حوضه ارس 
جدول f. خروجى وزن شاخصهاى متأثر از اندركنشهاى مكانى (rr)

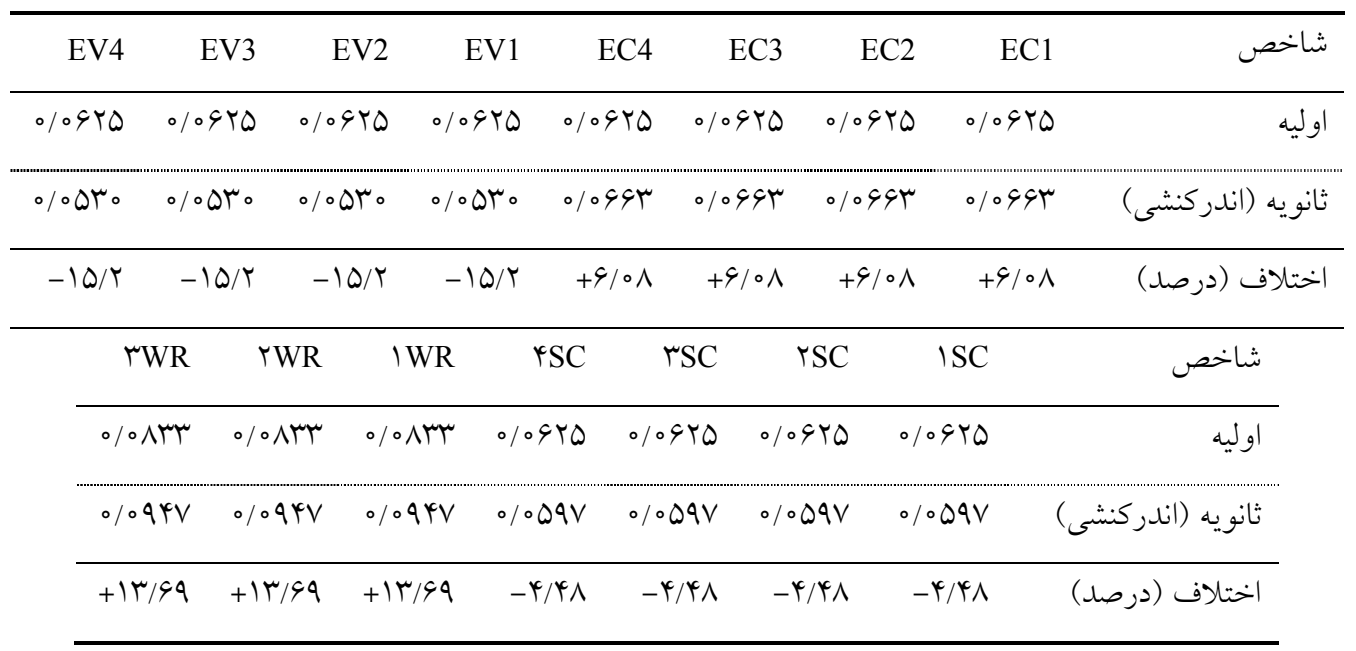

جدول ه. اولويتهاى نهايى و رتبه سناريوهاى تخصيص منابع آب

\begin{tabular}{|c|c|c|c|c|c|c|c|c|c|c|}
\hline \multicolumn{2}{|c|}{ ANP-SCP0.5 } & \multicolumn{2}{|c|}{ ANP-CP 0.5} & \multicolumn{2}{|c|}{$\operatorname{ANP}(23)$} & \multicolumn{2}{|c|}{ SCP0.5 } & \multicolumn{2}{|c|}{$\mathrm{CP} 0.5$} & \multirow{2}{*}{ سناريوها } \\
\hline رتبه & 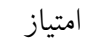 & رتبه & 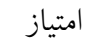 & رتبه & 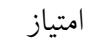 & رتبه & 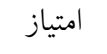 & رتبه & 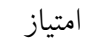 & \\
\hline Q & $0 / 1419$ & 0 & $0 / 1<91$ & r & - /190r & 0 &.$/ 1190$ & 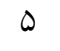 & - ITOQ & وضع موجود \\
\hline r & $0 / T \backslash 19$ & 1 &.$/ T Y 90$ & 1 & $\circ / T \circ \wedge \varphi$ & r & $\circ / Y 194$ & 1 & - MTQY & اجراى طرحهاى توسعه \\
\hline$r$ & $\circ / T \backslash M \Lambda$ & r & $0 / Y I Y Y$ & r & $\circ / Y \circ Y \mid$ & $r$ & $\circ / Y \backslash \wedge 。$ & $r$ & O/TITY & مديريت تقاضا \\
\hline 1 & - TYMAT & r & $\circ / T \| \mu$ & r & $\circ / Y \circ M Y$ & 1 & - TYTOA & $r$ & $0 / Y I F Q$ & تعادل بخشى آبهاى زيرزمينى \\
\hline$r$ &.$/ 1911$ & r &.$/ 1911$ & 0 & $\circ / \Lambda \wedge \mathrm{V}$ & r & $\circ / T Y \circ Y$ & r & OTYIT & خشكسالى و تغيير اقليم \\
\hline
\end{tabular}

تلفيق دو مدل، اعمال همزمان اثرات توزيع مكانى و اندركنشها را با استفاده از شاخصهاى توزيعى در اولويت نهايى سـناريوها ميسر مى كند. اولويت نهايى سـناريوهاى Se2 و Se4 بـا اعمـال توزيع مكانى اثرات آن بهصورت معكوس دجار تغيير مسىشـود.

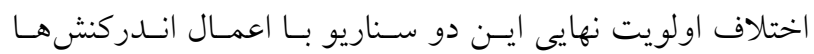
تعديل مىشود. اندركنشها و توزيـع مكـانى در بعضسى مـوارد همجهت و در برخى موارد، در خلاف جهت هم عمـل كـرده و اثر همديخر را تعديل مى كنــ (Se4). بنـابراين تلفيـق دو روش تور ارزيابى جندمعياره ANP-SCP در ارزيابى سناريوهاى تخصيص آب منجر به ارزيـابى در شـرايط واقعى و دقيـقتـر مسى شـود. اندركنشها ضرورتاً از طريق تحليل شبكهاى قابل اعمال اسـت. اثر نوع شاخص بر اولويت نهايى سناريوها با استفاده از جـدول
اندركنش ها در فرايند ارزيابى است (جدول \&). اولويت نهايی سناريوهاى تخصيص آب

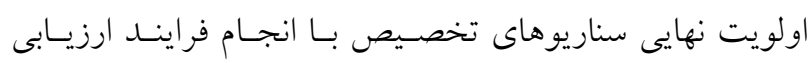
جنــدمعياره توسـط دو روش تحليـل شـبكهاى و برنامـهريـزى سازشى بلصورت منفرد و تركيبس بـا شـاخص هــاى تـودهاى و توزيعى در شكل ه ارائه شـده اسـت. در يــنج روش، سـناريوى

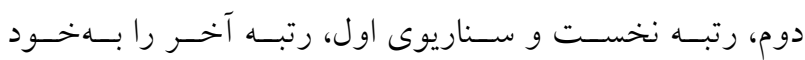
اختصاص دادهاند و سناريوهاى سوم و جهارم و ينجم، رتبههاى ميانى را كسب كردهاند (جدول ه).

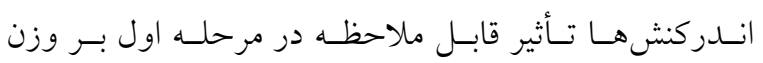
شاخصها و در مرحله دوم بـر اولويـت نهـايى سـناريوها دارد. 


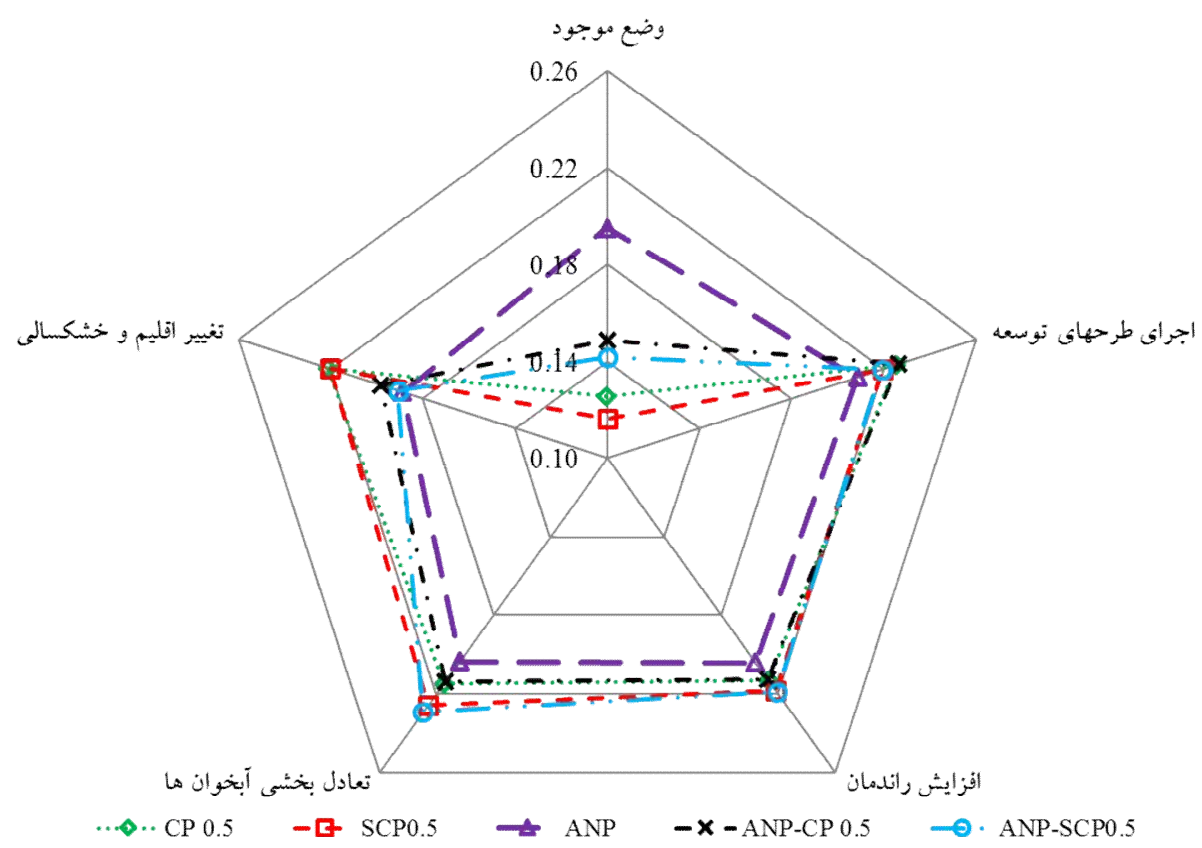

شكل ه. اولويت نهايى سناريوهاى تخصيص آب (رنخى در نسخه الكترونيكى)

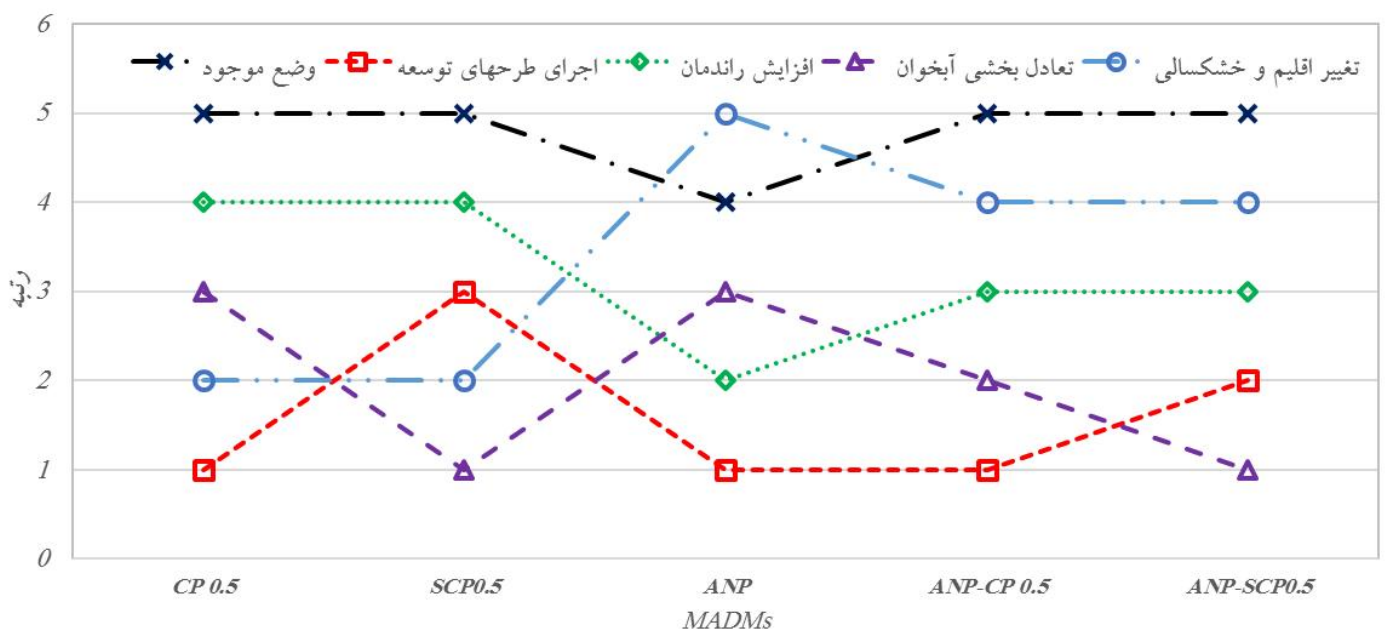

شكل 9. رتبه سناريوهاى تخصيص منابع آب حوضه ارس (رنكى در نسخه الكترونيكى)

ترى را نسبت به دو سناريوى Se1 و Se4 بهخود اختصاص داده

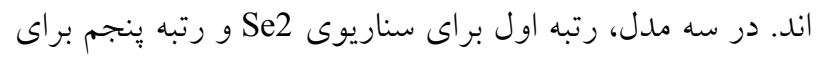
سناريوى Se1، جهار بار تكـرار شـــ اسـت. سـناريوهاى Se3، Se5 Se4 هركدام داراى دو بار تكرار در رتبهانـــ. ايسن نتسايج

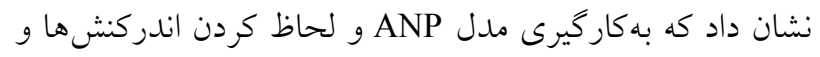

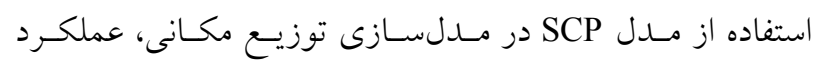

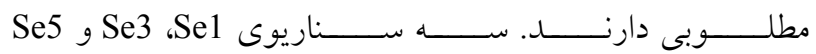

(D) بررسى شد و نشان داد كـه عـلاوه بـــر روش ارزيـابى، نــوع

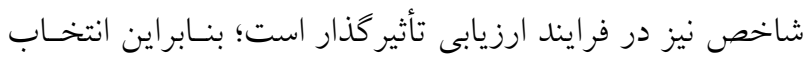

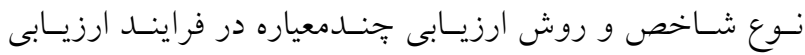
سناريوهاى تخصيص منابع آب حائز اهميت است.

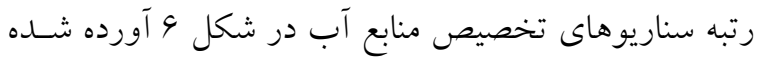

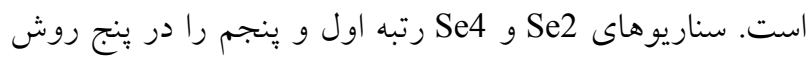
به دست آوردهاند و سناريوهاى Se3 و Se5، رتبههـاى متفـاوت 
جدول 4. مقادير ضرايب همبستخى اسبيرمن ينج نوع روش ارزيابى بهصورت زوجى

\begin{tabular}{|c|c|c|c|c|c|}
\hline $\mathrm{CP}$ & SCP & ANP & ANP-CP & ANP-SCP & مدل ارزيابى \\
\hline \multirow[t]{5}{*}{1} & $0 / 9$ & $0 / r$ & $\circ / V$ & $\circ / 0$ & $\mathrm{CP}$ \\
\hline & 1 & $-0 / 1$ & $\circ / 0$ & $\circ / V$ & $\mathrm{SCP}$ \\
\hline & & 1 & $\circ / \Lambda$ & $0 / 9$ & ANP \\
\hline & & & 1 & $\circ / 9$ & ANP-CP \\
\hline & & & & 1 & ANP-SCP \\
\hline
\end{tabular}

سازشى و تحليل شـبكهاى) و بيشـترين ضـريب همبسـتخى بـا مقدار 9/ه متعلـق بـه رتبـهبنـدى دو روش جنــدمعياره تركيبى (تحليل شبكهاى - برنامهريزى سازشى) با شاخص هاى تودهاى و توزيعى است. ضرايب همبستخى متنوعى براى زوج رتبهبندىها بـهدسـت

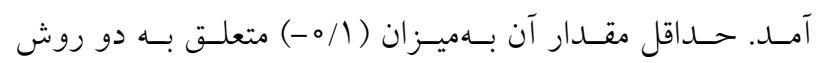
جندمعياره سـاده يعنى دو روش ANP و SCP اسـت. ضـريب همبستخى رتبهبندى ها با يك روش مشابه و با دو نوع شـاخص مختلف يعنى CP\&SCP بهميزان 9/ه محاسبه شد. ايسن ضـريب براى روش جندمعياره تركيبى مكانى (با شاخصهـاى تـوزيعى)

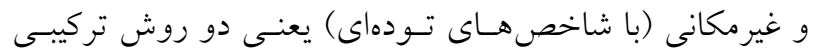
ANP-SCP همبسـتخى مــل تركيبى - مكـانى (ANP-SCP) بـا مـدلهـاى جندمعياره ساده شامل CP,SCP,ANP بهترتيب برابـر ه/ ه، V/ و /9/ محاسبه شد. ايسن نتـايج نشـان داد كـه توزيـع مكـانى و اندركنشها بهصورت همزمان تأثير قابـل ملاحظـهاى بـر نتـايج رتبهبندى سناريوهاى تخصيص منــابع آب برجـاى مسى كذارنـــ.

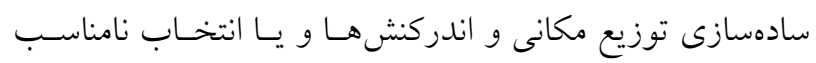
روش ارزيابى جنامعياره و نوع شاخص مىتواند منجر به عـدم قطعيت قابل توجه در فرايند ارزيابى شود.

\section{نتيجه گيرى}

در تحقيق حاضر، رويكرد ارزيابى جنــدمعياره مكـانى - تلفيقى بــراى ارزيـابى اتــرات ســاريوهاى تخصـيص آب بــر اسـاس
كه به توزيع مكانى حساسيت نداشتند به اندركنش ها حساسـيت نشان دادند بهطورى كه در مدل تحليل شبكهاى بـا تغييـر رتبـه

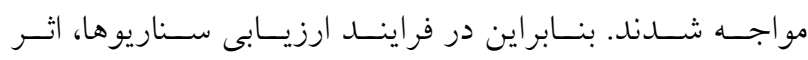
اندركنشها و توزيع مكانى هر دو قابل توجه هستند. بر اسـاس سناريوى منتخب حاصل از رويكرد تحليل جنــدمعياره تلفيقى، TOY ميليون متر مكعب براى نياز شرب با ضريب اطمينانيذيرى 9 درصد، MVDI ميليون متر مكعب نيازهاى غيرمصرفى شـامل زيست محيطى و برقـابى بـا ضـريب اطمينـانيــيرى بـانلاى درصد و 9004 ميليون متر مكعـب نيـاز كشـاورزى بـا ضـريب اطمينانيذيرى بالاى Vo درصد تأمين مىشود.

بحث در خصوص عملكرد روشهاى ارزيابى جندمعياره بهمنظور مقايسه نتايج ينج نوع رتبهبندى بهدسـت آمـده در ايسن

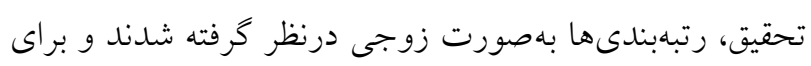
•ا زوج (C) اسبيرمن محاسبه و در جدول و آورده شد. اين زوج رتبهبندىها شامل دو روش جنــدمعياره مختلـف بــا شـاخص مشــابه مانتـــ ANP\&CP توزيعى مانند SCP\&CP و يا دو روش تجنـدمعياره مختلـف بـا شاخص هاى مختلـف ANP\&SCP اسـت همجنــين مـدل هــاى

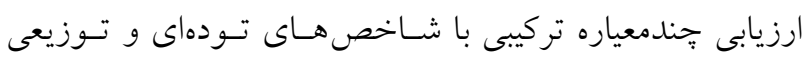

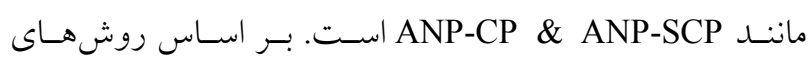

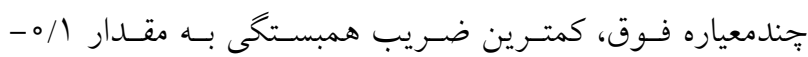
مربوط به رتبهبندىهاى دو روش جندمعياره ساده (برنامهريـزى 


$$
\begin{aligned}
& \text { به كارگيرى اين روش ارزيابى جندمعياره مكانى منجر به ارزيابى } \\
& \text { شاخصهاى توسعه بايدار و مديريت بهم بيوسته منـابع آب بـهـ } \\
& \text { دقيقتر اثرات مكانى سناريوهاى تخصيص آب مىشود. } \\
& \text { كار گرفته شد. توزيع مكانى اثرات سناريوهاى تخصسيص آب و } \\
& \text { - با وجود متناسب بودن روش تحليل شـبكهاى و روش برنامـه } \\
& \text { ريزى سازشى، استفاده هر يكى از ايـن دو روش بـهـتنهايى مسى } \\
& \text { تواند منجر به عدم قطعيت قابل ملاحظه بـا ضـريب همبسـتخى } \\
& \text { اسبيرمن // - - در نتايج شود. } \\
& \text { اندركنشهاى مكانى آنها بهعنوان دو ويزگ گیى كليـدى و اثرگـذار } \\
& \text { در فرايند ارزيابى بررسى شدند و نتايج ذيل بهدست آمد: } \\
& \text { - اعمال اندركنشها در فرايند ارزيابى، فقط از طريق بهكارگيرى } \\
& \text { روش تحليل شبكهاى امكانيذير است. براى انجام ايسن فراينـد، } \\
& \text { توسعه شبكهاى متشكل از كاسـترهاى معيارهـا، شـاخصىهـا و }
\end{aligned}
$$

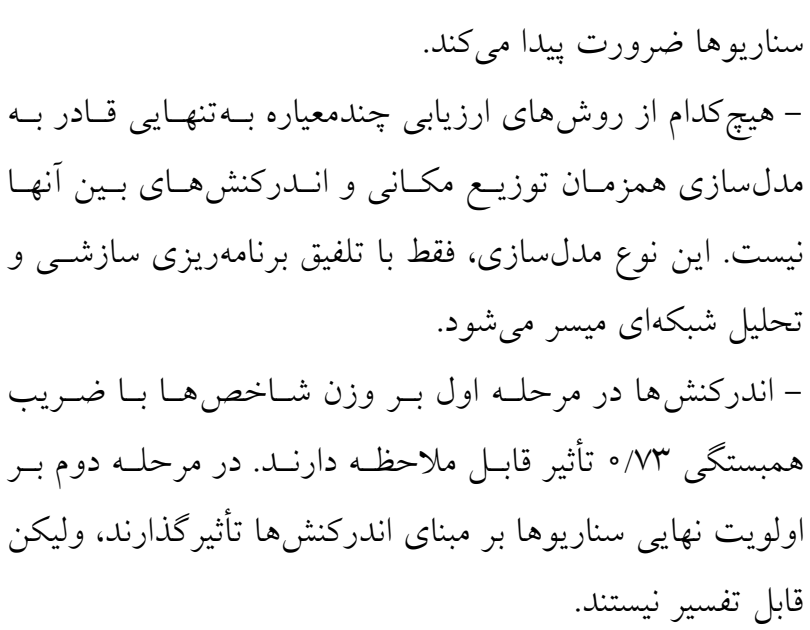

$$
\begin{aligned}
& \text { مكانى و اندركنشها در يكجهت موجب تقويت اولويت نهايى } \\
& \text { و در بعضى سناريوها نيز اين دو عامـل در خـلاف جهـت هــم } \\
& \text { عمل كرده و اثر همديخر را تعديل مى كنند. } \\
& \text { اين تحقيق نشان داد كه انتخاب نوع روش ارزيابى جندمعياره و } \\
& \text { نوع شاخص در فرايند ارزيابى نقش اساسى دارند و بهكـارگيرى } \\
& \text { رويكرد ارزيـابى جنــدمعياره مكـانى - تلفيقـى منجــر بـهـ بهبـود } \\
& \text { عملكرد فراينــد ارزيـابى سـناريوهاى تخصـيص آب مسىشـود. } \\
& \text { بهمنظور تعديل بيشتر عدم قطعيتها، انجام تحقيقات بيشترى با } \\
& \text { به كار گيرى تصميم گيرى گروهى موردنياز است. } \\
& \text { - روش برنامهريزى سازشسى عملكـرد مناسـبى در مــلسـازى } \\
& \text { توزيع مكانى اولويتهاى محلى با ضريب همبسـتكى } 9 / \text { ه دارد. }
\end{aligned}
$$

\section{منابع مورد استفاده}

1. Abrishamchi, A., A. Ebrahimian, M. Tajrishi and M. A. Mariño. 2005. Case study: application of multicriteria decision making to urban water supply. Journal of Water Resources Planning and Management 131(4): 326-335.

2. Afshar, A., M. A. Mariño, M. Saadatpour and A. Afshar. 2011. Fuzzy TOPSIS multi-criteria decision analysis applied to Karun reservoirs system. Water Resources Management 25(2): 545-563.

3. Brirhet, H. and L. Benaabidate. 2016. Comparison of two hydrological models (lumped and distributed) over a pilot area of the issen watershed in the Souss Basin, Morocco. European Scientific Journal 12(18): 347-358.

4. Dodge, Y. 2008. The Concise Encyclopedia of Statistics. Springer Science \& Business Media.

5. Falkenmark, M., J. Lundqvist and C. Widstrand. 1989. Macro-scale water scarcity requires micro-scale approaches: Aspects of vulnerability in semi-arid development. In: Natural resources forum 1989. Blackwell Publishing Ltd. Oxford, UK.

6. Geng, G. and R. Wardlaw. 2013. Application of multi-criterion decision making analysis to integrated water resources management. Water Resources Management 27(8): 3191-3207.

7. Ghavidelfar, S., S. R. Alvankar and A. Razmkhah. 2011. Comparison of the lumped and quasi-distributed Clark runoff models in simulating flood hydrographs on a semi-arid watershed. Water Resources Management 25(6): 1775-1790.

8. GWP, INBO. 2009. A Handbook for Integrated Water Resources Management in Basins. Global Water Partnership and International Network of Basin Organizations.

9. Hajkowicz, S. and K. Collins. 2007. A review of multiple criteria analysis for water resource planning and management. Water Resources Management 21(9): 1553-1566.

10. Hajkowicz, S. and A. Higgins. 2008. A comparison of multiple criteria analysis techniques for water resource management. European Journal of Operational Research 184(1): 255-265. 
11. Kim, Y. and E. S. Chung. 2014. An index-based robust decision-making framework for watershed management in a changing climate. Science of the Total Environment 473: 88-102.

12. Malekmohammadi, B., B. Zahraie and R. Kerachian. 2011. Ranking solutions of multi-objective reservoir operation optimization models using multi-criteria decision analysis. Expert Systems with Applications 38(6): 7851-7863.

13. Mendoza, G. A. and H. Martins. 2006. Multi-criteria decision analysis in natural resource management: A critical review of methods and new modelling paradigms. Forest Ecology and Management 230(3): 1-22.

14. Mokallaf Sarband, E., S. Araghinejad, J. Attari and K. Ebrahimi. 2019. Application of compromise programming method and fuzzy-spatial indicators for assessment of water allocation scenarios, (case study: Aras Basin) Iranian Journal of Soil and Water Research 50(5): 1265-1270. (In Farsi).

15. Montazar, A. and R. L. Snyder. 2012. A multi-attribute preference model for optimal irrigated crop planning under water scarcity conditions. Spanish Journal of Agricultural Research 10(3): 826-837.

16. Montazar, A. and E. Zadbagher. 2010. An analytical hierarchy model for assessing global water productivity of irrigation networks in Iran. Water Resources Management 24(11): 2817-2832.

17. Opricovic, S. 2011. Fuzzy VIKOR with an application to water resources planning. Expert Systems with Applications 38(10): 12983-12990.

18. Prodanovic, P. and S. P. Simonovic. 2002. Comparison of fuzzy set ranking methods for implementation in water resources decision-making. Canadian Journal of Civil Engineering 29(5): 692-701.

19. Radmehr, A. and S. Araghinejad. 2015. Flood vulnerability analysis by fuzzy spatial multi criteria decision making. Water Resources Management 29(12): 4427-4445.

20. Rahdari V., A. Soffianian, S. Pormanafi, H. Ghayomi Mohammadi, S. Maleki and V. Pormardan. 2020. Multicriteria evaluation for land rain- fed agriculture capability (a case study: Plasjan sub- basin). Journal of Water and Soil Science 23(4): 285-297. (In Farsi).

21. Saaty, T. L. 1996. Decision Making with Dependence and Feedback: The Analytic Network Process. RWS Publication.

22. Sarband, E. M., S. Araghinejad and J. Attari. 2020. Developing an interactive spatial multi-attribute decision support system for assessing water resources allocation scenarios. Water Resources Management 34(2): 447-462.

23. Srdjevic, B. and Y. D. P. Medeiros. 2008. Fuzzy AHP assessment of water management plans. Water Resources Management 22(7): 877-894.

24. Toosi, S. R. and J. M. V. Samani. 2017. Prioritizing watersheds using a novel hybrid decision model based on fuzzy DEMATEL, fuzzy ANP and fuzzy VIKOR. Water Resources Management 31(9): 2853-2867.

25. Vafaei, N., R. A. Ribeiro and L. M. Camarinha-Matos. 2016. Normalization techniques for multi-criteria decision making: analytical hierarchy process case study. In: Doctoral Conference on Computing, Electrical and Industrial Systems 2016. Springer, Cham.

26. Yang, J. S., E. S. Chung, S. U. Kim and T. W. Kim. 2012. Prioritization of water management under climate change and urbanization using multi-criteria decision-making methods. Hydrology and Earth System Sciences 16(3): 801814.

27. Zarghami, M., A. Abrishamchi and R. Ardakanian. 2008. Multi-criteria decision making for integrated urban water management. Water Resources Management 22(8): 1017-1029.

28. Zeleny, M. 1982. Compromise Programming. Multiple-Criteria Decision Making. New York McGraw-Hill Publishing. USA. 


\title{
Integrating Spatial Multi-Criteria Decision-Making Models for Evaluating Water Allocation Scenarios
}

\author{
E. Mokallaf Sarband ${ }^{1}$, S. Alimohammadi ${ }^{1}$, Sh. Araghinejad² and K. Ebrahimi2*
}

(Received: February 08-2020 ; Accepted: July 26-2020)

\begin{abstract}
In determining the allocation of water resources, the probable conditions of water resources and water demands are considered as the water allocation scenarios in the basin scale. Then, these scenarios are evaluated in the context of integrated water resources management and from the perspective of sustainable development indicators. The best scenario is selected in order to determine the water allocations. In these evaluations, there are spatial distributions and their interactions are simultaneously the key charaterictics in the decision matrix. These features are not often considered in the evaluation process. In the present study, distributed indicators and simple and integrated multi-criteria evaluation models, including ANP and CP methods, were used to evaluate the water allocation scenarios in the Aras Basin. The results showed that modeling of the spatial distribution and interactions of water allocation impacts was not possible through any of the simple multi-criteria evaluation methods. Simplifying and discarding one or two key features in the evaluation process can lead to significant uncertainties on rankings with a Spearman coefficient of - 0.1 . By implementing the integrated spatial decision-making approach and applying two features simultaneously, the fourth scenario was ranked first. The proposed approach was compared with the individual models, showing more accurate, with the correlation coefficients of $0.5,0.6$ and 0.7 .
\end{abstract}

Keywords: Integrated water resources management, Interactions, Spatial effects of water allocation.

1. Department of Water Resources Engineering, Faculty of Civil, University of Shahid Beheshti, Tehran, Iran.

2. Department of Irrigation and Reclamation Engineering University of Tehran Karaj.

*: Corresponding author, Email: ebrahimik@ut.ac.ir 